\title{
Examining High Rates of Preventable Maternal Mortality in Kenya Could Provisional Measures be an effective tool to Guarantee Safe Pregnancy?
}

\author{
Clara Burbano-Herrera* \\ Fulbright postdoctoral research fellow, \\ FXB Center for Health and Human Rights, Harvard University \\ cburbano@hsph.harvard.edu
}

\begin{abstract}
I went to Mama X's bed and found that she had taken off all her clothes and was sweating profusely. I enquired of her why she was completely undressed and she said that she felt like her body was on fire. She then pulled me closer to her and said "Nisaidie". I did not know what to do, so I went to Doctor P and told her what the patient had said. The doctor then told me "I am coming. Let me finish my round. You know, the patient's here are very dramatic. She should wait!" Taking her word for gospel truth, I went back to the patient and told her "Vumilfa tu mummy, daktari ankuja." I then went on checking on the other patients.
\end{abstract}

A few minutes later, she called me again and this time, in between gasps of air she told me "miguu zinaganda". She was losing sensation in her legs. I went to the doctor again and told her that the patient was losing feeling in her legs. More irritated than before, she waved me off and said in a stern voice "I will come once I'm done with the round." So I went back to the patient and said, "Tafadhali vumilfa tu mum, daktari anakuja."

The same lady called one of my colleagues and asked her to help. My colleague went to the doctor and was told the same thing. Since this patient had asked for help so many times we decided to tell one of the nurses and see whether they could help. Nurse A immediately came to where the patient was when we told her what was happening and decided that we needed to draw blood for grouping and cross matching before she was taken to theater. As soon as she fixed a cannula into the patients arm and started drawing blood, the patient collapsed. Nurse A began to shout and call for help. Everyone ran to where we were. The other nurses started trying to fix another cannula but the patients veins had already collapsed. She was in hypovolemic shock! Nurse D then shouted, "Call the doctor!" I rushed through the ward but could not find Doctor P anywhere. I then rushed out of the ward and to the theater and started shouting for help from any doctor. The staff there all just looked at me in shock, none responding in a matter suggesting that there was an emergency. Eventually Dr. P appeared and I told her that the patient was dying. She then responded "Bring the patient to theater." I asked "Shouldn't we try to resuscitate her first as we bring her?" The doctor responded, shouting "I've said bring the patient here! We'll resuscitate here!"

So I ran back to the ward and told them that the doctor said we wheel the patient to theater. Everyone started trying to transfer the patient onto the stretcher to take her to theater. As we lifted her off the bed, the only IV line that had been gotten came off. We then wheeled her to theater, as one of the students ran to the lab to get blood for transfusion. By the time the blood was gotten, the patient, mama $X$, had already passed on...

We all went back to the ward, emotions running high. We, the students were in total shock. The nurses sat at the nurses' desk and began discussing the matter. We overheard them say that it was our fault because we removed the only line that had been put in when transferring the patient onto the stretcher. We ignored this and decided to continue helping the ladies who were still trying to deliver. [...]

After this last ordeal, it was now time for us to leave. We were all distraught and depressed by what we saw that day. No human being should go through what those ladies delivering their children go through in that institution. ${ }^{\prime}$

* I would like to thank professor Alicia Yamin from Harvard University for her valuable comments on an earlier draft of this article.

1 Interview of medical student at Pumwani Maternal Hospital, Nairobi, Kenya, 25 May 2015 [on record with author]. Literal wording of the person interviewed, without language check. 
Despite legal advances in recognizing women's rights and putting in place public policies to improve maternal health, it is very common to read news articles, reports from human rights organizations, contributions from scholars and stories of the citizens describing the terrible conditions in which mainly poor women are attended in Kenyan' medical facilities. Mama X's is far from an isolated case. Kenya is rated among the 10 most dangerous countries worldwide for pregnant women. In this country the decrease of the maternal mortality rate (MMR) has been very little $^{2}$ - only 12 per cent - in 25 years. In 1990 the rate of maternal deaths amounted to 687 per 100.000 live births, in 2015 it amounted to $510,{ }^{3}$ while globally MMR fell from 385 deaths in 1990 to 216 in 2015, corresponding to a relative decline of 43,9 per cent. ${ }^{4}$

In Kenya, expectant mothers who are able to seek medical care in health care facilities is low: overall, only 44 per cent of births are delivered under the supervision of a skilled birth attendant; traditional birth attendants continue to assist with 28 per cent of births, relatives and friends with 21 per cent, and in 7 per cent of births mothers receive no assistance at all..$^{5}$ It is lamentable that less than half of the births are being delivered at health facilities under supervision of a skilled birth attendant, and even more lamentable that some expectant mothers are dying or frequently become seriously ill in health facilities due to inadequate health services, weak trained health personnel, professional negligence and inadequate infrastructure.

The World Health Organization (WHO) indicates that in Kenya in 2015 alone 8,000 expectant mothers died from pregnancy related complications. This means that each single day in Kenya 22 women died from preventable causes related to pregnancy and childbirth. Because maternal mortality predominantly impacts low income women from the Global South, and most of these deaths could have been prevented, maternal death in Kenya is a good example that shows that maternal mortality is also a problem linked to discrimination and inequality. ${ }^{6}$ Furthermore, elevated rates of preventable maternal mortality kept for a long period of time demonstrates the systematic failure of states in realising women's rights and the failure of states in addressing the structural disparities and problems underlying unsafe pregnancy.

Although several (direct and indirect) structural factors, including cultural, legal, economic and social factors such as women's low social status, malnutrition, lack of education and information, early marriage and unsafe abortions among others, could explain those deaths, this contribution focuses on maternal deaths connected to factors related

2 Maternal mortality is widely understood as the death of a woman while pregnant or within 42 days of termination of pregnancy, irrespective of the duration and site of the pregnancy and its mode of termination, from any cause related to or aggravated by the pregnancy or its management but not from accidental or incidental causes. WHO. International Classification of diseases (ICD-10). 10 ${ }^{\text {th }}$ Revision. Geneva: WHO; 2004. Available at <http://www.who.int/classifications/icd/en/>

3 See, WHO <http://www.who.int/reproductivehealth/publications/monitoring/maternal-mortality-2015/en/>

4 There were 303,000 maternal deaths worldwide in 2015. See, The Lancet, 2015, <http://www.thelancet.com/pb/assets/raw/Lancet/pdfs/S0140673615008387.pdf>

5 See, World Bank Report (2015). Available at <http://datatopics.worldbank.org/hnp/HNPMDG> and <http://databank.worldbank.org/data/Views/Reports/ReportWidgetCustom.aspx?Report_Name=HNP-MDG-5-Birth-attended-by-skilledhealth-staff\&Id=c2358f5f48\&inf=n\&zm=n.> The data related to Kenya is from 2009. See also Kenya Ministry of Health Policy Proposal. Available at <http://www.healthpolicyproject.com/ns/docs/kenyanewsfreematernalhealthattachment.pdf>. See also KNCHR, Implementing Free Maternal Health Care in Kenya, Challenges, Strategies, and Recommendations, N Bourbonnais, November 2013, p. 3. Available at <http://www.knchr.org/Portals/0/EcosocReports/Implementing\%20Free\%20Maternal\%20Health\%20Care\%20in\%20Kenya.pdf>

6 A major challenge in addressing maternal deaths is the lack of accurate data. Although knowledge on the number of women dying and the reasons behind their deaths is improving, much remains unrecorded and unreported. In many low-income countries, maternal deaths go indeed uncounted and frequently the cause of death is unknown or not recorded correctly, particularly when women die at home. See, WHO, Unicef, UNFPA and the World Bank, "Trends in Maternal Mortality: 1990 to 2013”, 1 (2014). See also L Say, D Chou, A Gemmill et al, "Global causes of maternal death: a WHO systematic analysis", (June 2014) 2/6 The Lancet Global Health. Available at <http://www.thelancet.com/journals/langlo/article/PIIS2214-109X(14)70227-X/fulltext.> 
to inadequate health-care services. The article intends to analyse the scenario in which expectant mothers are dying or become seriously injured in health facilities, frequently due to inadequate health services, weak trained health personnel, professional negligence and inadequate infrastructure. In the mentioned context, this contribution analyses the barriers that expectant mothers face in accessing appropriate and quality medical services in Kenya, and investigates the potential role of "provisional measures ${ }^{, 7}(\mathrm{PMs})$ (also called interim ${ }^{8}$ or 'precautionary' ${ }^{9}$ measures ${ }^{10}$ ) used by the regional African human rights adjudicator in protecting expectant mothers.

The aim of this article is to explore whether PMs adopted by the African Commission on Human and Peoples' Rights (African Commission or Commission) could be an appropriate legal tool to seek the protection of expectant mothers who are dealing with obstacles in obtaining the medical services that they need. In that regard, this contribution suggests that the situation of certain expectant mothers in Kenya meets the two necessary conditions to grant PMs under the African Human Rights system; i.e., the situation is urgent and the measures are necessary to prevent irreparable damages. ${ }^{11}$

The focus here falls on PMs rather than on findings on the merits, for 3 main reasons; (1) the immediacy of these measures makes them particularly relevant to expectant mothers. An ex post facto determination that a woman's rights had been violated may be important to establish state responsibility, but may easily render the affected women's rights illusory; (2) PMs are of primary importance in time-sensitive situations where an urgent response is called for, and (3) as appears from the discussion below, PMs in Africa have indeed almost never been invoked in the context of women's rights despite that the normative framework does not exclude the application of PMs to protect women or to protect the right to health and/or sexual and reproductive health rights. In fact the Commission granted 32 PMs between 1994 and 2015, and women were the group of beneficiaries with the lowest number of PMs granted. They were protected on only one occasion.

In order to comply with the mentioned aim, the article is divided in seven parts. (I) The first section deals with the normative basis, which gives competence to the African Commission to request PMs. It is mentioned that like under other systems the African human rights system does not distinguish between the quality of the persons or category of rights that may be protected through PMs. What it is relevant to request a PM is to demonstrate that there is a situation of danger and an objective fear that irreparable damages may occur if provisional measures are not adopted soon. It is also shown that PMs have mainly been applied to protect individualised persons, although they can also protect group of persons. The next section (II) considers the frequency of the use of PMs in the African Human Rights system. It is mentioned that the African Commission has adopted PMs in only 32 cases. The few number of PMs adopted could be the result of the fact that the Commission only can adopt PM when there is a communication before the system. However, it could be the case that the Commission has adopted PMs on more occasions but the public does not have access to this information because the Commission does not keep a record of such measures. It

7 The measures adopted by the African Commission and Court are called 'provisional measures'. See art 27(2) of the Court Protocol; $r 51$ of the Rules of Court and $\mathrm{r} 98$ of the 2010 Commission Rules of Procedure.

8 The measures adopted by the European Court of Human Rights are called 'interim measures' (in English) or 'provisional measures' (in French). See $r 39$ of the Rules of Court.

9 The measures adopted by the Inter-American Commission are called 'precautionary measures' and the measures adopted by the InterAmerican Court are called 'provisional measures'. See American Convention on Human Rights, art 63(2) and Rules of Procedure of the IACHR, art 25.

10 This contribution will refer to them as provisional measures or PMs.

11 African Commission's Rules of Procedure, r 98. See the text which accompanies footnote 14. 
could also be the case that the Commission has not made them public, obeying by the principle of confidentiality incorporated in Article 59 of the African Charter.

Taking into consideration that the African Commission has not granted PMs to protect expectant mothers, nor has it decided communications related to maternal mortality, section III analyses from an international comparative perspective cases in which states have been declared responsible for preventable maternal mortality, and cases in which PMs have been applied to protect expectant mothers in danger. The next section (IV) focuses on the Kenyan legal framework and it shows that from a formal perspective Kenya has committed to respect and protect women's rights, as Kenya has a modern constitution which incorporates sexual and reproductive health rights and it has also ratified international human rights treaties. In contrast, sections V and VI describe the real situation on the ground of expectant mothers - such as Mama X - who seek medical care. It establishes the critical condition of the Kenyan health facilities and the consequences on expectant mothers' basic rights. It suggests that the Commission, following the tendency of other international human rights bodies, has the potential to play a relevant role in the context of maternal mortality. The Commission should apply PMs ordering Kenya to improve the medical services offered to expectant mothers. Finally, the conclusion briefly emphasizes some aspects of maternal mortality and makes some recommendations.

\section{Legal Framework}

The fundamental purpose of provisional measures in the international system for human rights protection is to prevent irreparable harm of the rights of persons. ${ }^{12}$ Irreparable harm means the impossibility to rescuing the right threatened after the damage. It should be understood that once the damage has occurred, the granting of PMs does not make sense, and in such case it would then be necessary to await reparations from the state once its international responsibility has been declared. For this reason, the need of having an urgent situation also implies the impossibility of waiting for a judgment on the merits in order to adopt protective measures, because of the risk that during the lapse of this period the damage sought to be avoided occurs.

Provisional measures therefore have (a) a 'preventive function', in that they are issued to avoid violations of human rights, (b) a 'protective function', as they maintain a legal situation and at the same time they safeguard human rights, and (c) a 'precautionary purpose', as they allow states to act expeditiously to correct situations that may prima facie cause irreparable damages. In this sense, PMs that are complied with also provide states with the opportunity to impede the establishment of their international responsibility, because they are able to timely correct situations in which violations of human rights could occur. Compliance with PMs therefore shows respect for the human rights bodies which order them, and for the human rights themselves.

Consequently, applying PMs in cases related to maternal health do not seek the international responsibility of states for the violations of the rights of the women who already died. Their aim is to protect expectant mothers who are currently at risk.

12 For more information about PMs, see C Burbano-Herrera and F Viljoen, 'Provisional Measures Issued by the African Commission and African Court on Human and Peoples' Rights' in Y Haeck and C Burbano-Herrera (eds), Interim Measures in International Human Rights Law (forthcoming 2016 OUP); F Viljoen, International Human Rights Law in Africa (2012 OUP) 306; Eva Rieter, Preventing Irreparable Harm: Provisional Measures in International Human Rights Adjudication, Intersentia, Antwerp, 2010; and GJ Naldi, 'Interim Measures of Protection in the African System for the Protection of Human and Peoples' Rights' (2002) 2 African Human Rights Law Journal. 
The African Commission can adopt PMs with respect to Kenya and in general with respect to all African Union (AU) member States which have - with the exception of newcomer South Sudan - all ratified the African Charter. ${ }^{13}$ The legal basis of the Commission's competence to issue PMs can be found in Rule 98(1) of the Commission's 2010 Rules of Procedure, which says: ${ }^{14}$

\begin{abstract}
'At any time after the receipt of a Communication and before a determination on the merits, the Commission may, on its initiative or at the request of a party to the Communication, request that the State concerned adopt Provisional Measures to prevent irreparable harm to the victim or victims of the alleged violation as urgently as the situation demands.'
\end{abstract}

According to Rule 98 two cumulative conditions need to be met in order to seek the adoption of PMs; provisional measures should be necessary to prevent irreparable harm and the situation should be urgent.

Like under other systems, the African human rights system does distinguishes neither between the category of rights that may be protected through PMs, nor between the quality of the persons or groups of people who are in the situation of danger. What it is relevant to request a PM is to demonstrate that there is a situation of danger and an objective fear that irreparable damages may occur if PMs are not adopted soon. Furthermore, the facts on the basis of which the Commission may decide to act under the rules of procedure only requires a sufficient apprehension (rather than 'proof on a balance of probabilities or beyond reasonable doubt') of the existence of 'urgency', mainly because the order of PMs does not prejudge the merits of the communication. However, it is not suggested here that the African Commission may adopt PMs in every difficult situation holding the potential of harm, as not all potential violations of rights would result in 'irreparable damage' to the person concerned. It should indeed be borne in mind that PMs are principally of an exceptional nature, and that the main aim pursued by human rights supervisory organs is to avoid irreparable harm.

Since the Commission's Rules of Procedure do not assign any meaning to the concepts 'irreparable harm' and 'urgent' and because the African Commission does not adopt reasoned decisions on PMs, it is problematic to conduct a rigorous analysis of the circumstances giving rise to PMs. Nonetheless, the rare cases in the African system where a PMs has been adopted demonstrate that the African Commission considers as especially grave the damage that may be suffered by persons over whom the State is a guarantor, such as persons to be or handed over to the state authorities. For example, detainees have been protected in a number of instances, including those alleging unlawful arrest ${ }^{15}$ and condemnation to death, ${ }^{16}$ and being kept in appalling conditions. ${ }^{17}$

13 The Institute for Human Rights and Development in Africa, a Banjul-based NGO, publishes the decisions of PMs of the African Commission and Court. Available at: <http://caselaw.ihrda.org.> The Centre for Human Rights of the University of Pretoria also publishes the decisions of PMs on its website. Available at <http://www.chr.up.ac.za/index.php/browse-by-subject/538-interimprovisional-measures.html.>

14 The Commission incorporated the competence to adopt PMs in 1988 in its first set of Rules of Procedure, (r 109). When it amended its Rules of Procedure in 1995, the Commission elaborated upon its competence to adopt PMs in r 111. Since 2010, the restated competence to adopt PMs has been contained in Rule 98. See C Burbano-Herrera and F Viljoen, above at note 12.

15 Communication 140/94, 141/94 and 145/95, Constitutional Rights Project, Civil Liberties Organisation and Media Rights Agenda v Nigeria, paras 2 and 49; and Application 2/2013, African Commission (in respect of Saif Al-Islam Gaddafi) v Libya.

16 Egyptian Initiative for Personal Rights and Interights $v$ Arab Republic of Egypt.

17 Communication 137/94, 139/94, 154/96 and 161/97, International Pen, Constitutional Rights Project, Interights (in respect of Ken Saro-Wiwa Jr and Civil Liberties Organisation) v Nigeria; Communication 140/94, 141/94 and 145/95, Constitutional Rights Project, Civil Liberties Organisation and Media Rights Agenda v Nigeria and Application 2/2013, African Commission (in respect of Saif Al-Islam Gaddafi) v Libya para 15 
Given the special situations of danger in Africa, the Commission has adopted PMs in order to protect individualized persons and also groups of people. However, most of the cases are related to individualized beneficiaries. The African Commission has adopted PMs in a collective character on only two ocassions. In one case PMs were granted in order to protect some victims of the armed conflict in Djibouti and in another case PMs were awarded in order to protect approximately 15,000 indigenous members of the Ogiek Commnunity of the Mau Forest, with regard to whom Kenya had for many years committed a series of acts and omissions such as harassment and arbitrary forced evictions without consultation or compensation. ${ }^{18}$

Although the African Charter makes some social and economic rights unequivocally justiciable, ${ }^{19}$ in particular the right to education ${ }^{20}$ and the right to health, ${ }^{21}$ the case law on PMs seems biased, in that PMs are, with very rare exceptions, adopted in order to protect traditional civil and political rights. Until now PMs adopted by the African Commission have protected the right to health in only a single matter. ${ }^{22}$ It is therefore ironic that the Commission has made more sparing use of these seemingly more generous legal standards. It remains to be seen if in future cases PMs will be adopted by the Commission in respect of serious situations related to the violation of socio-economic rights, for example resulting from the lack of medication or adequate medical treatment of persons who are very ill and lacking financial resources, or who are at risk due to manifestly inadequate housing or basic education.

\section{Case law of the African Comission on Human and Peoples' Rights}

Although PMs are intended to prevent irreparable harm to people in a situation of serious risk, such measures have been adopted very rarely in Africa. Indeed, while the African Commission has been competent to adopt PMs for some 27 years, from 1988 to $2015,{ }^{23}$ they have been granted on only 32 occasions. ${ }^{24}$ Furthermore, PMs have mostly

18 Communication 133/94, Association pour la Défense des Droits de l'Homme et des Libertés v Djibouti (2000) AHRLR 80 (ACHPR 2000) and Application 6/2012, African Commission (in respect of the Ogiek Community of the May Forest) v Kenya.

19 African Charter, art 22.

20 Ibid, art 17.

21 Ibid, art 16

22 The Commission in Nigerian Newspapers Proscription case required the state to ensure that the health of the victims was not endangered. See above at note 15

23 The Commission has the competence to adopt PMs since 1988, but the first time that a PM was adopted was in 1993 . Between 1 January 1993 and mid-2014, according to information available, 22 out of 28 PMs requests were granted.

24 See Communication 83/92, Jean Yakovi Degli v Togo; Saro-Wiwa case (n 17 above) two decisions; Communication 140/94, 141/94 and 145/95, Constitutional Rights Project, Civil Liberties Organisation and Media Rights Agenda v Nigeria; Communication 212/98, Amnesty International v Zambia (2000) AHRLR 325 (ACHPR 1999); Communication 133/94, Association pour la Défense des Droits de l'Homme et des Libertés v Djibouti (2000) AHRLR 80 (ACHPR 2000); Communication 290/2004, Open Society Justice Initiative (in respect of Njawe Noumeni) v Cameroon (2006) AHRLR 75 (ACHPR 2006); Communication 284/03, Zimbabwe Lawyers for Human Rights \& Associated Newspapers of Zimbabwe $v$ Republic of Zimbabwe; Communication 334/06, Egyptian Initiative for Personal Rights and Interights $v$ Arab Republic of Egypt;Kordofan Provisional Measures v Sudan; Communication xx/12, Centre for Human Rights, University of Pretoria (in respect of David Mendes) v Angola; Communication 430/2012, Gabriel Shumba and Others (Represented by Zimbabwe Lawyers for Human Rights) v Zimbabwe; Gaddafi's son Provisional Measures case (n 17 above); application 6/12, African Commission v Kenya (concerning the Ogiek of Mau Forest Area; Communication 239/2001, Interights (in respect of Sikunda) v Namibia, (2002) AHRLR 21 (ACHPR 2002); Communication 256/2002, Woods and Another v Liberia, (2003) AHRLR 125 (ACHPR 2003); Communication 250/2002, Zegveld and Another v Eritrea, (2003) AHRLR 84 (ACHPR 2003); Communication 258/2002, Miss A v Cameroon, (2004), AHRLR 39 (ACHPR 2004); Communication 269/03, Interights (in respect of Safia Yakubu Husaini et al) v Nigeria; Communication 231/99, Avocats Sans Frontières (in respect of Bwampamye) v Burundi, (2000) AHRLR 48 (ACHPR 2000; Communication 260/02, Bakweri Land Claims Committee v Cameroon (2004) AHRLR 43 (ACHPR 2004) and Communication 276/03, Centre for Minority Rights Development (Kenya) and Minority Rights Group (in respect of Endorois Welfare Council) $v$ Kenya. Eleven of which were adopted from May 2014 to April 2015 . There is no public information about the substantive content of the last eleven PMs adopted. Report of the Chairperson of the Working Group on Communications, Commissioner Lucy Asuagbor, presented during the 56th Ordinary Session of the African Commission, Banjul, Gambia, 21 April-7 May 2015. 
protected detainees, ${ }^{25}$ and have only on one occasion been granted by the African Commission to protect an individualised woman. ${ }^{26}$

Given the number and severity of the human rights violations committed across Africa during this period, the question must be asked why so few PMs have been issued by the Commission and almost never to protect women, especially given that - with the exception of newcomer South Sudan -, all AU member States have ratified the African Charter $^{27}$ and most have been a state party since the 1990s and therefore have fallen under the supervision of the African Commission for quite some time now. ${ }^{28}$

As to the small number of requests for PMs by the African Commission, some of the contributing factors could be that their adoption requires a communication pending before the Commission, and that some cases are not publicly accessible because the Commission does not keep a record or list of such requests. The lack of information on numbers can be deducted from the African Commission's words in its final decision in the Saro-Wiwa case. After the State had quite deliberately failed to comply with the Commission's request to suspend death penalty orders, the Commission stated that "executions had been stayed in Nigeria in the past on the invocation by the Commission of its rules on provisional measures and the Commission had hoped that a similar situation would obtain in the case of Ken Saro-Wiwa and others. It is a matter of deep regret that this did not happen”. ${ }^{29}$ However, prior to this finding, there is no official record or registration whatsoever of PMs issued related to Nigeria.

Furthermore, it is also not certain how many PMs the Commission has not been allowed to publish on the basis of the application of Article 59(1) of the African Charter. Under this provision, all measures taken within the provisions of Chapter III 'Procedure of the Commission' of the African Charter shall remain confidential until such a time as the Assembly of Heads of State and Government shall otherwise decide.

\section{Preventable Maternal Mortality in an International Human Rights Framework}

Taking into account that the African Commission has not granted PMs to protect expectant mothers or decided communications related to maternal mortality, this section will examine whether other international human rights bodies have applied PMs to protect expectant mothers in a situation of danger and whether they have declared states internationally responsible for preventable maternal death. A comparative study shows that international and national organs have applied human rights law to hold governments legally accountable for the preventable maternal death of women. The study also shows that in the Americas PMs have been requested with the aim to protect expectant mothers. Overall, these decisions highlight the gaps in the health-care system from the perspective of pregnant women, they establish that governments are legally accountable for filling those gaps, and they emphasise the link between maternal mortality, poverty, discrimination and inequality.

International Responsibility due to Preventable Maternal Mortality

25 C Burbano Herrera and F Viljoen, 'Danger and Fear in Prison: Protecting the Most Vulnerable Persons in Africa and the Americas by Regional Human Rights Bodies Through Interim Measures' (2015) Netherlands Quarterly of Human Rights 163-193.

26 The beneficiary was a Nigerian nursing mother sentenced to death by stoning by a sharia court for the alleged crime of adultery. See Communication 269/03, Interights (in respect of Safia Yakubu Husaini et al) v Nigeria.

27 The African Union is an international organization and since South Sudan joined it in 2011, it consists of 54 African states. Today, 54 of the 55 states are member of the AU. The exception is Morocco, which has withdrawn from the Organization in 1984, after the AU recognised the Western Sahara as a sovereign state.

28 The African Charter had been ratified by all member states of the (AU) by 1999 .

29 Saro-Wiwa case (n 17 above) para 103. 
UN treaty bodies (TBs) supervising state's commitments under the core UN human rights treaties have pointed out that the prevention of maternal mortality and the right to safe pregnancy and childbirth are part of the right to life, the right to health, the principle(s) of equality and non-discrimination and the freedom from cruel, inhuman and degrading treatment. ${ }^{30}$ They have indicated that elevated rates of maternal mortality are related - among others ${ }^{31}-$ to the lack of comprehensive reproductive health services. ${ }^{32}$ They have also stated that states should take targeted measures to address maternal mortality in marginalized groups that have disproportionately elevated rates of maternal death, including with regard to young women, ${ }^{33}$ low-income women ${ }^{34}$ and women from rural areas. ${ }^{35}$

The Human Rights Committee (HR Committee) was the first treaty body to clearly indicate in 1982 that states must adopt positive measures to protect the right to life. ${ }^{36}$ This Committee has indicated that states have a fundamental duty to protect individuals from arbitrary and preventable loss of life, ${ }^{37}$ including from preventable maternal death. ${ }^{38}$ Similarly, the Committee on the Elimination of Discrimination against Women (CEDAW Committee) ${ }^{39}$ and the Committee on the Rights of the Child (CRC Committee) ${ }^{40}$ have explicitly interpreted the right to life to include state obligations to prevent and address maternal mortality. ${ }^{41}$ These treaty bodies have shown concern for Kenya's high levels of maternal death, lack of quality of health care, lack of basic infrastructure and abusive behaviour from medical staff towards patients. ${ }^{42}$

In the first ever maternal death case (Alyne da Silva Pimentel v Brazil) the CEDAW Committee in 2011 established that preventable maternal mortality is an international violation of state obligations. ${ }^{43}$ The CEDAW Committee found that Brazil had breached its obligations under the Convention on the Elimination of All Forms of

30 See, e.g., CAT Committee, Concluding Observations: Peru, para 15, U.N. Doc. CAT/C/PER/CO/5-6 (2013); Paraguay, para 22, U.N. Doc. CAT/C/PRY/CO/4-6 (2011); Alyne da Silva Pimentel Teixeira v Brazil, CEDAW Committee, Communication No. 17/2008, paras 7.5-7.6, U.N. Doc. CEDAW/C/49/D/17/2008 (2011); Concluding Observations: Brazil, paras 28-29, U.N. Doc. E/C.12/BRA/CO/2 (2009); Human Rights Committee, Concluding Observations: Mali, para 14, U.N. Doc. CCPR/CO/77/MLI (2003); Mongolia, para 8(b), U.N. Doc. CCPR/C/79/Add.120 (2000); Peru, para 20, U.N. Doc. CCPR/CO/70/PER(2000); Trinidad and Tobago, para 18, U.N. Doc. CCPR/CO/70/TTO (2000); CEDAW Committee, Concluding Comments: Belize, para 56, U.N. Doc. A/54/38/Rev1 (1999).

31 TBs have also indicated that elevated rates of maternal mortality are related to abortion laws and unsafe or illegal abortion. See, Human Rights Committee, Concluding Observations: Chile, para 15, U.N. Doc. CCPR/C/CHL/CO/6 (2014); Panama, para 9, U.N. Doc. CCPR/C/PAN/CO/3 (2008); CEDAW Committee, Concluding Observations: Paraguay, para 13, CCPR/C/PRY/CO/3 (2013); Eritrea, para 22, U.N. Doc. CEDAW/C/ERI/CO/3 (2006); Guatemala, para 20, U.N. Doc. CCPR/C/GTM/CO/3 (2012).

32 CEDAW Committee, Concluding Observations: Mexico, para 30-31, U.N. Doc. CEDAW/C/MEX/CO/7-8(2012).

33 CRC Committee, Concluding Observations: Nicaragua, paras 64-65, U.N. Doc. CRC/C/NIC/CO/4 (2010).

34 HR Committee, Concluding Observations: Argentina, para 14, U.N. Doc. CCPR/CO/70/ARG (2000).

35 ESCR Committee, Concluding Observations: Brazil, para 28, U.N. Doc.E/C.12/BRA/CO/2 (2009).

36 The HR Committee monitors state compliance with the International Covenant on Civil and Political Rights.

37 HR Committee, General Comment No. 6, art 6 (Right to Life) (Sixteenth session, 1982), Compilation of General Comments and General Recommendations Adopted by Human Rights Treaty Bodies, U.N. Doc. HRI/GEN/1/Rev1 at 6 (1994) para 5. Available at <http://www1.umn.edu/humanrts/gencomm/hrcom6.htm>

38 HRC, General Comment No. 28: Equality of Rights between Men and Women, (68th Sess., 2000), in Compilation of General Comments and General Recommendations adopted by Human Rights Treaty Bodies, at 229, para 10 U.N. Doc. HRI/GEN/1Rev9 (Vol. 1) (2008). Available at 〈http://www1.umn.edu/humanrts/gencomm/hrcom28.htm>

39 The CEDAW Committee monitors state compliance with the CEDAW. CEDAW Committee, General Comment No. 24: Art 12 of the Convention (women and health), (20th Sess., 1999), in Compilation of General Comments and General Recommendations Adopted by Human Rights Treaty Bodies, at 365, para 31(c), U.N. Doc. HRI/GEN/1/Rev9 (Vol. 11) (2008).

40 The CRC monitors state compliance with the Convention on the Rights of the Child.

41 See, CEDAW Committee, Concluding Comments: Belize, para 56, U.N. Doc.A/54/38/Rev1 (1999) (“[T]he Committee notes that the level of maternal mortality due to clandestine abortions may indicate that the Government does not fully implement its obligations to respect the right to life of its women citizens."); HR Committee, Concluding Observations: Mali, para 14, U.N. Doc.CCPR/CO/77/MLI (2003) ("So as to guarantee the right to life, the State should strengthen its efforts in ensuring the accessibility of health services, including emergency obstetric care."); CRC Committee, Concluding Observations: Democratic Republic of Congo, U.N. Doc. CRC/C/COD/CO/2, para 33-34 (2009).

${ }^{42}$ On this see below text which accompanies notes $86,88,89$ and 90 .

43 The CEDAW Committee requires that State parties ensure women appropriate services in connection with pregnancy, childbirth and postnatal period including family planning and emergency obstetric care. See Alyne da Silva Pimentel Teixeira v Brazil, CEDAW Committee, Communication No. 17/2008 (10 August 2011), paras 7.6 \& 7.7, U.N. Doc. CEDAW/C/49/D/17/2008 (2011). Available at <http://www.ohchr.org/Documents/HRBodies/CEDAW/Jurisprudence/CEDAW-C-49-D-17-2008_en.pdf> 
Discrimination Against Women (CEDAW) in failing to prevent a maternal death. It was found that Alyne, a 28year-old woman, died because she was not provided with appropriate health care to treat obstetric complications related to her pregnancy. This decision establishes as a matter of international law that governments have human rights obligations to guarantee that all women in their countries, regardless of income level or racial background, have access to timely, non-discriminatory and appropriate maternal health services in public and private health facilities. ${ }^{44}$ This is the first decision in which the Committee has specifically required that a state provides adequate and quality maternal health care services as part of its non-discrimination obligations (Article 12(2) CEDAW). ${ }^{45}$

From a regional perspective the Inter-American Court of Human Rights (IACtHR) found Paraguay in violation of the right to life (Article 4(1) American Convention) and the right to exercise that right without discrimination (Article 1(1)) of Remigia Ruiz. She was an expectant mother and indigenous woman who died at 38 years age. ${ }^{46}$ The IACtHR held Paraguay responsible for Remigia's maternal death and described that the circumstances of her death were: death during labour without adequate medical care, a situation of exclusion or extreme poverty, lack of access to adequate health services and a lack of documentation on cause of death. ${ }^{47}$

At the national level, in 2010 the High Court of Delhi (India) found the government in violation of Shanti Devi's constitutional right to life and health (Article 21) for her preventable death in childbirth. ${ }^{48}$ Having been denied their legal entitlements to hospital care for those living below the poverty line, Shanti had to give birth at home without a skilled attendant. She died immediately thereafter, leaving a husband and three living children. The direct cause of her death was postpartum haemorrhage due to a retained placenta. The contributing factors included her socioeconomic status, which resulted in her being denied needed resources and services, and her poor health condition resulting from anemia, tuberculosis and repeated unsafe pregnancies.

Recently, in 2015 the High Court of Uganda established the responsibility of the local government for the death of Nanteza Irene who did not receive the timely, immediate and emergency obstetric care that she needed to overcome the obstructed labour condition she was in. ${ }^{49}$ The direct cause of the death was ruptured uterus secondary to anemia. Nanteza was in the hospital during eight hours and the doctor on duty arrived at the hospital only a few minutes before she died. The Court held the local government responsible for the violation of the deceased right to access appropriate medical and health services, the deprivation of the children of their right to be cared for by their mother, and the suffering and mental anguish that her husband and son have had to go through as a result of the loss of life of Nanteza. This decision evidences that preventable maternal mortality violates several rights and affects multiple

44 Ibid para 7.6. Even when governments outsource health services to private institutions, the Committee found that they remain responsible for their actions and have a duty to regulate and monitor private health centres.

45 See also, RJ Cook, "Human rights and maternal health: Exploring the effectiveness of the Alyne decision", 201341 Global Health and the Law 103-23.

46 Xakmok Kasek Indigenous Community v Paraguay, Merits, Reparations and Costs, Judgment, IACtHR, 24 August 2010, paras 2,214,217, $232,234,275,301,303$ and 306.

47 The decision related to Remigia's death was part of an indigenous lands petition, where the Court ruled the failure of the government to guarantee the Xakmok Kasek indigenous peoples possession of their ancestral property kept this community in a vulnerable state regarding its health and welfare. See above at note 46 paras 214,232,273.

48 Laxmi Mandal v Deen Dayal Harinagar Hospital, Ors W.P.

49 High Court of Uganda, Civil Suit No. 111 of 2012, 30 April 2015, 12. 
people. It constitutes a violation of the rights of the women who do not obtain adequate medical care while having complications during pregnancy or delivering, and it violates the rights of their relatives who suffer their loss. ${ }^{50}$

Four points deserve to be mentioned with regard to the decisions mentioned above: (1) national and international human rights organs are becoming very clear in indicating that maternal mortality is a human rights issue and States may be declared (inter)nationally responsible for those deaths; (2) preventable maternal mortality is the result of the systematic failure of the States in putting in place adequate policies to guarantee women a safe pregnancy. Those deaths are not natural, and that is why maternal mortality is a problem that only certain women from the Global South suffer; (3) maternal mortality affects mainly women from disadvantaged groups in society, including from low income groups, being part of a minority group such as indigenous or black women, and women who live in rural areas; (4) finally, maternal mortality does not affect only the women who die but also their entire families who are left behind.

\section{Provisional Measures for the Protection of Expectant Mothers at risk}

Expectant mothers in a situation of extreme danger have been protected by PMs under the Inter-American human rights system. ${ }^{51}$ The cases in which PMs have been granted have had as a purpose that expectant mothers obtain the medical treatment they need to protect their rights. In these cases, the lack of medical treatment that expectant mothers are in need of predominantly leads to the loss of the foetus. As will be established, the requests for PMs have made visible the legal and social obstacles that pregnant women have to deal with in obtaining the medical treatment they need.

In these cases both the Inter-American Commission on Human Rights (IACHR) and the IACtHR have requested the state concerned to provide the medical treatment recommended by the doctors. For example, the IACHR requested Nicaragua to protect Amelia, a 27 years old woman with cancer and mother of a 10 year old girl. She was not allowed to receive the necessary medical attention to treat the cancer she suffered because of her pregnancy. The doctors had recommended Amelia to urgently initiate chemotherapy or radiotherapy treatment, but the hospital informed Amelia's mother and representatives that the treatment would not be given, due to the high risk that it could provoke an abortion.

Since 2006, in Nicaragua abortion is banned under all circumstances, even when the pregnancy is the result of rape or incest, or even when the mother's life or her health is in danger. ${ }^{52}$ Currently, Nicaraguan doctors are prohibited from treating pregnant women with cancer, HIV/AIDS, malaria and cardiac diseases, and they are also threatened with prison sentences for providing health services or information related to abortion. Within the deadline set to receive an answer, Nicaragua informed the IACHR that the requested treatment had been initiated. ${ }^{53}$

In another case, the Inter-American Court granted PMs to protect a pregnant woman known as 'B'. She suffered from lupus and her foetus was determined to have anencephaly, a condition in which a major part of the brain is

\footnotetext{
50 Alicia Yamin has done extended research on this issue. See, for example Women's Lives Matter: The Impact of Maternal Death on Families \& Communities. Available at <http://fxb.harvard.edu/womens-lives-matter/>

51 The authorisation to request the adoption of PMs in the Inter-American system is governed by the American Convention, the Rules of Procedure of the Inter-American Court and Commission, i.e., art 63(2) of the Convention, art 26(1)(2)(3) of the Rules of the Court and art 74(1) of the Rules of the Commission.

52 Nicaraguan Penal Code, art 16.

53 IACHR, MC 43-10, Amelia v Nicaragua, 26 February 2010.
} 
absent. ${ }^{54}$ The absolute ban of abortion in El Salvador prevented the doctors from terminating the pregnancy in order to protect 'B's rights. ${ }^{55}$ In the PM resolution the IACtHR requested El Salvador to adopt the necessary measures in order for B's doctors to perform the procedures they considered opportune and desirable to avoid irreparable harm to B's rights to life, personal integrity and health. The Court, citing medical opinions, concluded that the situation of 'B' was urgent and in terms of irreparability the Court indicated that if B's pregnancy progressed, she could suffer from severe medical complications or death, in addition to harm to her mental health. The measures were lifted five days after they were granted. Indeed, meanwhile, B had gone into labour and the doctors had performed a caesarean section.

The case law mentioned leads us to conclude that PMs in the Americas have been an important tool to protect expectant mothers in a situation of danger. It also shows that if international human rights bodies take their function of protecting expectant mothers seriously - at least from the perspective of women who were beneficiaries of PMs -, they may have an enormous impact in terms of guarantying women's rights in practice. However, when a woman dies due to complications during pregnancy or while delivering as a consequence of the lack of adequate and appropriate medical care, as happened to Mama X, it must be clear that those deaths are not natural and several rights are violated: the right to life (Article 4 African Charter), right to health (Article 16), freedom from discrimination (Article 2), right to equality (Article 3) and the women's reproductive rights (Article 14 Maputo Protocol).

\section{Applying Provisional measures within the African Human Rights Framework}

\section{Kenyan Legal Framework: The Obligation to Respect, Protect and Fulfill Women's rights}

Kenya provides strong legal protection to women's rights both at the national and international level. At the African Union level Kenya ratified the African Charter $^{56}$ on Human and Peoples' Rights, ${ }^{57}$ which, although it is silent on women's rights in general and reproductive rights in particular, provides a set of general human rights, including the right to life and integrity (Article 4), the right to health (Article 16) and the freedom from discrimination (Article 2). ${ }^{58}$ Additionally, Kenya has ratified the Protocol to the African Charter on the Rights of Women in Africa (Maputo Protocol), which provides for women's health and sexual and reproductive health rights (Article 14). ${ }^{59}$ This is the main legal instrument for the protection on the rights of women in Africa. It commits state parties to establishing and strengthening existing pre-natal, delivery and post-natal health and nutritional services for women. ${ }^{60}$ Kenya has also ratified the African Charter on the Rights and Welfare of the Child, which indicates that every child shall have

54 IACtHR, PM, B v El Salvador, 19 August 2013.

55 Salvadorean Penal Code, Art 133-37.

56 The African Charter was adopted in Nairobi (Kenya) on 27 June 1981, entered into force on 21 October 1986.

57 The African Commission has meanwhile adopted various guidelines and resolutions on different relevant issues. These include the Guidelines on Economic, Social and Cultural Rights in the African Charter (2005), the Resolution on Maternal Mortality (2008), the Resolution on the health and reproductive rights of women, the Resolution on the status of women in Africa and the Resolution on the situation of women and children in Africa.

58 F Viljoen, 'An introduction to the Protocol to the African Charter on Human Rights and Peoples' Rights on the Rights of Women in Africa', (2009) 16 Washington and Lee journal of Civil Rights and Social Justice 19.

59 The substance of the Charter has been extended by the adoption of the Maputo Protocol, over which the African Commission and Court also have jurisdiction, including the competence to issue PMs. It was ratified by Kenya on 8 October 2010. Kenya entered a reservation on art $14(2)$ (c) disallowing legal abortion in cases of rape and defilement and where the life and health of the mother and foetus are in danger. This is inconsistent with Article 26(4) of the 2010 Kenyan Constitution.

60 The African Commission published General Comment No 2 on art 14.1(a)(b)(f) and Article 14.2(a)(c) of the Maputo Protocol. Available at $<$ http://www.achpr.org/instruments/general-comment-two-rights-women/.> 
the right to enjoy the best attainable state of physical, mental and spiritual health (Article 14(1)). ${ }^{61}$ It also indicates that states should ensure appropriate health care for expectant and nursing mothers (Article 14(2)(e)).

At the UN treaty level, Kenya has ratified seven of the nine core human rights treaties, ${ }^{62}$ and these provide a relevant human rights framework for the protection of women's rights. ${ }^{63}$ It concerns the International Convention on the Elimination of All Forms of Racial Discrimination (CERD), ${ }^{64}$ Covenant on Civil and Political Rights (ICCPR), ${ }^{65}$ the Covenant on Economic, Social and Cultural Rights (ICESCR) ${ }^{66}$ the Convention on the Elimination of All Forms of Discrimination against Women (CEDAW) ${ }^{67}$ the Convention Against Torture and Other Cruel, Inhuman or Degrading Treatment or Punishment (CAT), ${ }^{68}$ the Convention on the Rights of the Child (CRC) ${ }^{69}$ and the Convention on the Rights of Persons with Disabilities (CRPD). ${ }^{70}$

At the national level Kenya has a modern Constitution which entered into force in 2010. In terms of formal recognition of women's rights the Kenyan Constitution is very generous. Furthermore, according to the Constitution, human rights treaties ratified by Kenya are an integral part of the national law. ${ }^{71}$ In its Article 43(1)(a) the Constitution guarantees to every person the right to the highest attainable standard of health, which includes the right to health care services and reproductive health care. Therefore, reproductive health is widely recognized and it includes family planning, antenatal, delivery and postnatal health services. Next to this, according to Article 26(4), abortion is permitted if in the opinion of a trained health professional the life or health of the mother is in danger. ${ }^{72}$ The Constitution takes special care of poor women and women in a special situation of vulnerability. It indicates that no one shall be denied emergency medical care (Article 43(2)) and that the state shall provide appropriate social security to persons who are unable to support themselves and their dependants (Article 43(3)). It mentions that children and minorities and marginalized groups have the right to access to health services (Articles 53 and 56). More broadly, the Constitution recognizes the right to inherent dignity and the right to have that dignity respected and protected (Article 28). The Constitution also creates two organs with the function to supervise that the rights and freedoms recognized in the Constitution are effectively enjoyed by women, namely the Kenya National Commission

61 The African Charter on the Rights and Welfare of the Child was adopted in Addis Ababa, Ethiopia on 11 July 1990 , entered into force on 29 November 1999. The African Children's Committee is the supervisory body. By ratifying the African Children's Charter, States automatically accept the competence of the African Children's Committee to 'receive' individual and inter-State communications. See, OAU Doc. CAB/LEG/24.9/49 (1990), Articles 32, 43 and 44. However, this body does not have an explicit competence to adopt PMs. Kenya ratified this Charter on 25 July 2000. Available at <http://www1.umn.edu/humanrts/africa/afchild.htm>

62 Kenya has not ratified the International Convention on the Protection of the Rights of All Migrant Workers and Members of their Families, which was adopted on 18 December 1990; and the International Convention for the Protection of all Persons from Enforced Disappearance which was adopted on 20 December 2006.

63 State reporting is a mandatory requirement of the nine core UN human rights treaties. Each of these treaties requires states to submit initial reports to be followed by periodic reports indicating the measures they have taken to implement the rights enumerated in the treaties. See generally UN Manual on human rights reporting (1997).

64 It was adopted on 21 December 1965, entered into force on 4 January 1969, ratified by Kenya on 13 September 2001.

65 It was adopted on 16 December 1966, entered into force on 23 March 1976, ratified by Kenya on 1 May 1972.

66 It was adopted on 16 December 1966, entered into force on 3 January 1976, ratified by Kenya on 1 May 1972.

67 It was adopted on 18 December 1979, entered into force on 3 December 1981, ratified by Kenya on 8 April 1984.

68 It was adopted on 10 December 1984, entered into force on 26 June 1987, ratified by Kenya on 21 February 1997.

69 It was adopted on 20 November 1989, entered into force on 2 September 1990, ratified by Kenya on 26 June 1990.

70 It was adopted on 13 December 2006, entered into force on 3 May 2008, ratified by Kenya on 19 May 2008.

71 Constitution, art 2(6).

72 The 2010 Kenyan Constitution has relaxed the rigidity on termination of pregnancy that existed previously. The Penal code previously criminalized the attempt to procure a miscarriage by a third party (art 158), the attempt to procure a miscarriage by the women herself (art 159 ) and the supply of drugs to procure a miscarriage (art 160). These carried a heavy penalty of 14 years, 7 years and 3 years in prison, respectively. 
on Human Rights (KNCHR) ${ }^{73}$ and the National Gender Equality Commission (NGEC). ${ }^{74}$ The KNCHR Act 2011 confers the Commission functions to investigate on its own initiative or upon a complaint made by any person or group of persons the violation of any human rights. ${ }^{75}$ Over the last years, this Commission has undertaken public inquiries covering violations of reproductive health rights. ${ }^{76}$ As will be shown in the next section, the KNCHR examined the conditions of the hospitals, including maternal hospitals, and published a report in 2012. This report points out the deplorable services that expectant mothers receive while in the medical centres.

The Kenyan authorities have also developed several policies and strategies targeting sexual and reproductive rights and launched campaigns against maternal death, such as the National Road Map for Accelerating the Attainment of the MDGs Related to Maternal and New-born Health in Kenya (2010), ${ }^{77}$ the National Reproductive Health Strategy $(2009-2015)^{78}$ and the Kenya Health Policy (2012-2030). ${ }^{79}$ One of the campaigns specifically aimed at fighting against maternal death was 'Campaign beyond Zero, ${ }^{80}$ which in 2014 led to the creation of the 'Beyond Zero Foundation' which partners with the government in reducing maternal mortality.

\section{Context of the Kenyan' Health Facilities}

It is well documented that Kenyan health facilities suffer from lacks of resources, infrastructure, equipment, staffing and quality of services. These factors explain why expectant mothers, such as Mama X, die in health facilities or after being attended in one of them. The World Bank's 2013 report on Kenyan health facilities found that only 44.6 per cent of public health providers could properly manage maternal/neonatal complications. ${ }^{81}$ Only 36 per cent of the public health facilities offering delivery services have the basic delivery room infrastructure and equipment needed. ${ }^{82}$ Furthermore, Kenya's public health facilities have long been plagued by reports of abuse, mistreatment and negligence of patients at the hands of staff. ${ }^{83}$

73 The KNCHR was first established as a statutory body in 2003 pursuant to the KNCHR Act (No 9) of 2002. In August 2011 the KNCHR was reconstituted into a constitutional commission by art 59(4) of the 2010 Constitution. The Act outlines the mandate of the Commission, among them being competent to conduct investigations into any complaint on the violation of human rights in the country.

74 The NGEC was established by an Act of Parliament in August 2011, as a successor commission to the Kenya National Human Rights and Equality Commission pursuant to art. 59 of the Constitution. The NGEC's objectives are promoting gender equality and freedom from discrimination.

75 In September 2009, the Federation of Women Lawyers-Kenya (FIDA Kenya) and the Centre for Reproductive Rights-USA (CRR) submitted a complaint to the KNCHR on allegations of violations of women's reproductive health rights in Kenyan health facilities, specifically concerning the Pumwani Maternity Hospital. The complaint was based on the findings of a study they had jointly conducted between November 2006 and May 2007 among a sample of women, health care providers, hospital administrators, leaders of medical associations, and officials of licensing and regulatory bodies. The report 'Failure to Deliver' found that the Kenya was responsible for various severe reproductive health rights violations. Available at <http://reproductiverights.org/sites/default/files/documents/pub_bo_failuretodeliver.pdf.>

76 KNCHR, Realizing Sexual and Reproductive Health Rights in Kenya. A Myth or Reality?, 2012.

77 Available at <https://www.k4health.org/sites/default/files/Roadmap\%20to\%20Maternal\%20and\%20Newborn\%20Health\%20Booklet.pdf>

78 Available at $\langle$ https://www.k4health.org/sites/default/files/National\%20RH\%20Strategy_0.pdf>

79 Available at 〈http://countryoffice.unfpa.org/kenya/drive/FinalKenyaHealthPolicyBook.pdf $>$

${ }_{80}$ Information about the campaign may be found in its website: <http://www.beyondzero.or.ke/>

81 H Martin and O Imphidzai, Education and Health Services in Kenya: Data for Results and Accountability, Service Delivery Indicators: Education/Health, Washington, DC: International Bank for Reconstruction and Development/The World Bank, July 2013, 2-4; see also KNCHR below note 84 at 8 .

82 KNCHR above at note 76 at 48,49 .

83 KNCHR, Implementing Free Maternal Health Care in Kenya, Challenges, Strategies, and Recommendations, N Bourbonnais, 2013, at 6,7 Available at <http://www.knchr.org/Portals/0/EcosocReports/Implementing\%20Free\%20Maternal\%20Health\%20Care\%20in\%20Kenya.pdf> We Need Accountability, Not Money, To Fix The Health Sector, The Star, 2013. Available at <http://www.the-star.co.ke/news/article130247/we-need-accountability-not-money-fix-health-sector>. Free Maternity Services in Kenya Could Endanger Mothers' Lives, Experts Warn, 2013. Available at <http://www.standardmedia.co.ke/> 
Over the years the national human rights institutions,${ }^{84}$ international human rights bodies, ${ }^{85}$ international UN-related non-human rights institutions, ${ }^{86}$ (inter)national non-governmental organizations ${ }^{87}$ and the media have extensively and publically informed about the terrible situation in which expectant mothers are attended in public hospitals. They have constantly requested Kenya to improve sexual and reproductive health services. Consequently, state authorities have been well informed about problems around medical services related to expectant mothers.

In 2012 the Kenya National Commission on Human Rights arrived at the same conclusions presented by the CEDAW Committee in 2007. ${ }^{88}$ The latter had indicated that the maternal mortality rate in Kenya remained high and that " $[\ldots][T]$ he Committee is deeply concerned about women's lack of access to quality sexual and reproductive health services [...]. It is also concerned that negative attitudes of health workers may be an impediment to women's access to health-care services [...]." ${ }^{, 89}$ The Committee recommended Kenya to step up its efforts to reduce the incidence of maternal mortality, and to ensure that health workers adopt a client-friendly attitude that will lead to improved access to quality health care. ${ }^{90}$ In 2011, the CEDAW Committee repeated its remarks with respect to Kenya. The Committee "was [...] particularly concerned that maternal mortality rates have increased [...] and [as to] women's limited access to quality reproductive and sexual health services [...]." ${ }^{\prime 91}$ Importantly, in 2011, the CEDAW Committee in a case related to Brazil, conceptualized and applied the accountability for preventable death in justiciable terms. ${ }^{92}$

In turn, the Committee on Economic, Social and Cultural Rights (ESCR Committee) ${ }^{93}$ has indicated that states' obligations to guarantee maternal health care - including prenatal and post-natal care - are comparable to a core obligation ${ }^{94}$ under the right to health. ${ }^{95}$ In 2008, the ESCR Committee pointed out the high rates of maternal deaths in Kenya. This Committee, as the CEDAW Committee, also referred to "[...] the lack of adequately equipped maternal health care facilities and skilled birth attendance, $[\ldots]$ and de facto discrimination against poor women, older women and women with HIV/AIDS in access to maternal health care". The Committee recommended Kenya to take immediate measures "to ensure that all expectant mothers $[\ldots]$ have affordable access to skilled care free from abuse during pregnancy, delivery, postpartum, postnatal periods, and to care of the new-born, including in

84 Ibid at 3. KNCHR above note at 76; See also Kenya Ministry of Health Policy Proposal. Available at <http://www.healthpolicyproject.com/ns/docs/kenyanewsfreematernalhealthattachment.pdf>.

85 The CEDAW Committee and the ESCR Committee. On this see above text which accompanies notes 88-96

86 World Bank Report (2013). Available at <http://datatopics.worldbank.org/hnp/HNPMDG> and $<$ http://databank.worldbank.org/data/Views/Reports/ReportWidgetCustom.aspx?Report_Name=HNP-MDG-5-Birth-attended-by-skilledhealth-staff \&Id=c2358f5f48\&inf=n\&zm=n.> The data related to Kenya is from 2009.

87 See above note at 75 .

88 On this see below text which accompanies note 112 .

89 CEDAW Committee, Concluding Comments: Kenya, 10 August 2007, para 37 CEDAW/C/KEN/CO/6. Available at <http://www.refworld.org/docid/46d280ff6.html>

90 Ibid para 38

91 CEDAW Committee, Concluding Comments: Kenya, 5 April 2011, paras 37-38 CEDAW/C/KEN/CO/7. Available at <http://www2.ohchr.org/english/bodies/cedaw/docs/co/CEDAW-C-KEN-CO-7.pdf>

92 On this see above text which accompanies notes 44 and 45.

93 The ESCR Committee monitors state compliance with the ICESCR. An important landmark for the definition of the right to health was the adoption of General Comment No. 14 of the UN ESCR Committee, which outlines the framework of the 'highest attainable standard of health' in art 12 ICESCR. The component of the right to health as expounded in General Recommendation No. 14 of the Committee, which requires that the services must be available with sufficient health facilities and trained health professionals. See, KNCHR above at note 83 at 4. Available

<http://www.knchr.org/Portals/0/EcosocReports/Implementing\%20Free\%20Maternal\%20Health\%20Care\%20in\%20Kenya.pdf>

94 Core obligations are the minimum essential level of each right that states must immediately realize.

95 ESCR Committee, General Comment No. 14: The right to the highest attainable standard of health (art. 12), (22nd Sess., 2000), in Compilation of General Comments and General Recommendations Adopted by Human Rights Treaty Bodies, at 80-81, para 12, U.N. Doc. HRI/GEN/1/Rev9 (Vol. 1) (2008), paras 14,21. 
remote rural areas [...]. ${ }^{96}$ While the Committee against Torture (CAT Committee) ${ }^{97}$ has not made a reference to Kenya, it has expressed concern about the high maternal mortality rates around the world, indicating that preventable maternal deaths may violate protections against the right to freedom from cruel, inhuman and degrading treatment. ${ }^{98}$

Although state authorities have put in place diverse actions to address the issue, the desired results have not been obtained. This is most probably due to lack of integral and real understating of the problem. For example, on 1 June 2013 Kenya initiated a policy of free maternity services in all public facilities with the aim to improve the access to medical service. ${ }^{99}$ Health facilities soon began to feel the effect of this policy. Hospitals were ill-prepared because they did not have the capacity to respond adequately to a higher number of expectant mothers that they were already used to receive. Increased overcrowding in maternity wards was reported, with some mothers forced to leave the hospital early to make room for others, or even deliver on the floor due to lack of beds. ${ }^{100}$ Nurses have also reported being overburdened due to the new policy, with nearly all working overtime and as few as three nurses aiding 20 mothers at a time. ${ }^{101}$ On the day of the announcement of the aforementioned new government policy the Pumwani Maternity Hospital, which is the largest hospital in the country, delivered an unprecedented 100 births and it was uncertain of how to balance the new policy for free care with their need to cover costs. ${ }^{102}$ A matron for example noted that while the hospital used to charge Sh 5,000 (47 euros) for normal deliveries and Sh 10,000 (95 euros) for a caesarean, the government was reimbursing them at a flat rate of Sh 5,000 per delivery, creating a critical financial gap. $^{103}$

The critical situation of expectant mothers in health facilities has also been affected by other factors. For example, four months after free maternal health care was implemented (in September 2013) the Pumwani Maternal Hospital was closed for some days after employees boycotted duty in an ongoing strike by Nairobi county government workers. ${ }^{104}$ In May 2015, it was reported that since the previous year, 2,000 doctors had quit public services because of their alleged poor treatment by county governments. ${ }^{105}$

96 CESCR Committee, Concluding Observations E/C.12/KEN/CO/1 1 December 2008, para $32 . \quad$ Available at <http://docstore.ohchr.org/SelfServices/FilesHandler.ashx?enc=4slQ6QSmlBEDzFEovLCuW2MbmIr6bjcj69OB9bDJS0h6wnzTN86b8rPdV p2riZPw4cBjzaTfLoZp3OAnmL1knuEha0fsDxAF2IbbocyN\%2f6SjUE\%2bEHqLvoKUmHEW2xPDU>

97 The CAT Committee oversees compliance by states with the Convention against Torture and Other Cruel, Inhuman or Degrading Treatment or Punishment.

${ }^{98}$ CAT Committee, Concluding Observations: Paraguay, para 22, U.N. Doc. CAT/C/PRY/CO/4-6 (2011); Peru, para 15, U.N. Doc. CAT/C/PER/CO/5-6 (2013).

99 "Speech by H.E. Hon. Uhuru Kenyatta, C.G.H., President and Commander-in-Chief of the Defence Forces of the Republic of Kenya During the Madaraka Day Celebrations" (Nyayo National Stadium, 1 June 2013). Available at <http://www.statehousekenya.go.ke/.>

${ }^{100} \mathrm{KNCHR}$ above at note 83 at 6-7.

${ }^{101}$ Ibid at 6, referring to "Free Maternity Services in Kenya Could Endanger Mothers' Lives, Experts Warn". Available 18 July 2013 , <http://www.standardmedia.co.ke/.>

102 "Despite Newly Free Deliveries in Kenya, Some Mothers Opt for Traditional Birth Attendants," Women Deliver, July 24, 2013. Available at <http://www.womendeliver.org/updates/entry/despite-newly-free-deliveries-in-kenya-some-mothers-opt-for-traditional-bir.> See also KNCHR above at note 83 at 3 .

${ }^{103} \mathrm{KNCHR}$ above at note 83 at 6.

${ }^{104}$ More than 2,000 nurses at the Kenyatta National Hospital went on strike, demanding fulfilment of a promised 46 per cent increment in their basic pay awarded by the High Court in September 2012. See KNCHR above at note 83 at 8.

105 With the new Constitution, the responsibility of primary health care, including the financing and management of health facilities, falls on county governments. 2013 World Bank Report, Wide variation in per capita government spending and health personnel between counties indicates wide disparities in the ability of public agencies at the local level to provide adequate health care. For example, Isiolo county spends KES 1,800 per person on health, while Mandera spends less than KES 200. Available at <http://www.worldbank.org/content/dam/Worldbank/document/Africa/Kenya/kenya-economic-update-june-2013.pdf> See also Daily Nation News. Available at <http://www.nation.co.ke/news/2000-doctors-have-quit-public-service/-/1056/2654670/-/gnbwgj/-/index.html> 
Additionally, Kenya only allocates 4.5 per cent of its total budget to health (2014-2015), which is well below Kenya's commitment to the 2001 AU Abuja Declaration, which requires states to allocate at least 15 per cent of their national budgets to public health by $2015 .{ }^{106}$ In fact, the current budget of 4.5 per cent in 2014-15 is a decrease from rates of 5.9 per cent in 2012, 6.1 per cent in 2011, and 7.2 per cent in $2010 .^{107}$

\section{Applying Theory to Practice: Adopting Provisional Measures to Protect Expectant Mothers being attended at Pumwani Maternal Hospital}

Although the situation of the medical centres in Kenya is in general critical, for methodological reasons it has been decided to select the Pumwani Maternal Hospital (Pumwani or Pumwani Hospital) to explain how a PM should be granted in order to protect pregnant women in situation of danger. This hospital was visited by the author of this contribution in April 2015, and interviews were conducted. ${ }^{108}$

Pumwani is situated in Nairobi and is the busiest maternity hospital in East and Central Africa, with an average of 80-100 deliveries per day. ${ }^{109}$ This means that it handles between 29,000 and 36,000 deliveries per year, i.e., the highest number of assisted deliveries in Kenya. ${ }^{110}$ As of 2005, 80 per cent of all the deliveries that occur in Kenyan health facilities took place at this hospital. ${ }^{111}$ Most expectant mothers who seek medical services at Pumwani Maternal Hospital are poor and young. In this sense, PMs granted with regard to this hospital could have an important impact in terms of number of women protected by the measure and PMs could also have an impact in terms of combating social injustice.

In the lines below it will be explained why the two necessary conditions for requesting PMs are met in the case of expectant mothers being attended at Pumwani. After this, the content of the resolution of PMs that the African Commission could request will be described.

\section{Condition 1: Situation of danger}

The situation of danger at Pumwani Hospital has been researched and denounced on multiple occasions and for a long time. Academic contributions and reports prepared by national institutions and NGOs have arrived to the same findings; Pumwani has several structural problems related to infrastructure, shortages of staff, lack of supplies and equipment, deplorable behaviour of staff, lack of appropriate skills of hospital staff and weak external supervision

106 Institute of Economic Affairs, 'Kenya Budget 2014/2015: Balancing financing concerns while responding to spending inefficiencies', 2014, 13.

107 See UNAIDS, Abuja +12 Shaping the future of health in Africa. 2013. Available at <http://www.unaids.org/sites/default/files/media_asset/JC2524_Abuja_report_en_0.pdf>

108 Staff of the Kenyan Legal and Ethical Issues Network on HIV \& AIDS (KELIN), The Kenya National Commission on Human Rights, The National Gender Equality Commission, FIDA-KENYA, Federation of Women Lawyers.

109 K Wycliffe, Socio-cultural Factors Influencing Nutritional Status among Women Attending Pumwani Maternity Hospital, University of Nairobi, Kenya, 2010. Available at <http://researchkenya.or.ke/node/37011.> See also African Renewal at <http://www.un.org/africarenewal/magazine/january-2008/investing-health-africa\%E2\%80\%99s-mothers>, and Smart Global Health Organization, information available at <http://www.smartglobalhealth.org/blog/entry/studying-kenyas-largest-maternity-hospital/> See also, KNCHR above at note 82 at 168.

110 See interview with Pumwani's chief executive officer, Fridah Govedi, in 2011. Available at <http://www.irinnews.org/report/92229/kenyanurses-go-slow-highlights-ills-at-maternity-hospital>. See also in 2014, the online newspaper 'All Africa' mentioned that the hospital has 80 delivers per day, and All Africa "Kenya: First Lady Donates Eight Incubators to Pumwani Maternity Hospital". Available at $<$ http://allafrica.com/stories/201409030225.html>.

111 KNHRC above at 76 at 168 . 
systems. ${ }^{112}$ These problems put expectant mothers who seek medical attention at Pumwani Hospital in danger. The Federation of Women Lawyers-Kenya, together with the Centre for Reproductive Rights-USA, and the Kenya National Commission on Human Rights published reports on this in 2007, in 2009 and in 2012. ${ }^{113}$ These reports indicate that women suffer from unsafe conditions for delivery, lack of sensibility to the cultural norms and beliefs of the people in service delivery, as well as abusive behaviour by the staff. Some of the problems mentioned in these reports were witnessed by the author of this contribution during the visit she conducted in the hospital, and they were also confirmed by the interviewees. These structural problems put in danger the rights of expectant mothers whom seek medical services at Pumwani. These factors have contributed to high rates of maternal and infant mortality, lasting psychological and physical repercussions and loss of public confidence in the hospital in general and in the health care system in particular. Furthermore, the critical situation at the Pumwani Hospital is well known by state authorities and society at large, because the media has continuously covered the violations of rights which have occurred in the hospital. ${ }^{114}$ To give an idea of the magnitude of the problem, all the interviewees responded that they would never bring their wife, daughter, mother or a female friend to Pumwani Hospital because of the risk these women could die due to the bad health services offered there.

The measures adopted by the State over the years, such as the ratification of international human rights treaties, the constitutional recognition of the right to life, the right to health, sexual and reproductive health rights as well as the campaigns launched against maternal death and the policy of free maternal services in all public facilities, are important signs which demonstrate that states authorities are concerned, however, they have clearly been insufficient. ${ }^{15}$

\section{Condition 2: Irreparable damages}

Expectant mothers currently staying as patients at Pumwani Maternal Hospital, are at risk of suffering damage of their rights. Their rights could be irreparably harmed because these women are remaining in the same precarious conditions and under similar circumstances as those expectant mothers who already died as a consequence of inadequate medical services. They are all in need of protection. ${ }^{116}$ In this context, the PMs must be requested to protect all expectant mothers being attended at the Pumwani Maternal Hospital, whom can be identified by two objective criteria, i.e., being pregnant and being at the Pumwani Hospital. In this case, although the exact number of beneficiaries will not be indicated, from the list of expectant mothers that each maternal hospital has to have, the number of women could be deduced. ${ }^{117}$

The intervention of the African Commission through PMs would aim to prevent irreparable violations to the right to life (Article 4 African Charter), the right to health (Article 16), the freedom from discrimination (Article 2), the right to equality (Article 3) and reproductive rights (Article 14 Maputo Protocol). PMs will be framed as an order for

${ }^{112}$ See KNCHR above at note 82 .

${ }^{113}$ See above note at 75 .

${ }^{114}$ In google there are several news published regarding the topic. See <https://www.google.com/webhp?sourceid=chromeinstant\&ion=1\&espv=2\&ie=UTF-8\#q=pumwani\%20maternity\%20hospital\%20on\%20stryke >

115 See above Part V 'Context of the Kenyan Health Facilities'.

116 See above text which companies footnote 113.

117 The Commission can request the protection of non-identified persons. In these cases, beneficiaries are not identified by name and the Commission normally does not know exactly who or how many the beneficiaries are. The Commission identified them by objective elements and can deduce where they are in order to offer the protection they need. See text which accompanies footnote 18. 
Kenya to put in place specific measures, which will ensure that expectant women obtain the medical care they need. In a broader perspective, PMs will ensure that pregnant women enjoy effectively their fundamental rights, which have been recognised in international human rights treaties ratified by Kenya.

\section{The Content of the Requested Provisional Measures}

The current situation of medical facilities in Kenya illustrates the negligence by the State in the fulfilment of its obligations. Kenya has failed to adopt effective measures to ensure respect for women's rights and to guarantee them the enjoyment of their basic rights (Article 14(2)(b) Maputo Protocol). ${ }^{118}$ The request for PMs implies that the African Commission orders Kenya, on the basis of Rule 98 of the Commission's Rules of Procedure and Article 1 of the African Charter, ${ }^{119}$ to adopt a series of measures to protect expectant mothers who are currently being attended at the Pumwani Maternal Hospital. The Commission should request Kenya to take specific measures to address maternal mortality in order to protect women's basic rights. More concretely, the Commission should request:

1. To forthwith adopt any measures that may be necessary to prevent unduly maternal deaths of all expectant mothers who are being attended at Pumwani Maternal Hospital

2. To hold that the following measures be adopted forthwith, i.e.: a) To hire an adequate number of health professionals who have the necessary skills to provide adequate medical attention; $b$ ) To ensure that the Pumwani Maternal Hospital has the necessary medical equipment and well-equipped rooms to offer expectant women the medical services they need; c) To ensure that the Pumwani Maternal Hospital has the basic essential obstetric care services as indicated by the WHO. It should include at least the following: parenteral antibiotics, parenteral oxytocic drugs, parenteral sedatives for eclampsia, manual removal of placenta, and manual removal of retained products. Comprehensive essential obstetric care services should include surgery, anesthesia and blood transfusions; d) To provide special training to health professionals with the aim that they offer the health care that expectant mothers need, and ensure that health professional attend expectant mothers with respect, and being sensitive to their cultural norms and believes; e) To provide expectant mothers, both in terms of quantity and quality all the medical care that may be need; and f) To take the measures with the participation of the women and the complainants.

3. To request the State to investigate the facts that have given rise to the adoption of the provisional measures, and if the case may be, to identify those who are responsible therefore and to provide for the corresponding punishment, including administrative and disciplinary sanctions.

4. To request the State to inform the Commission, within 15 days following service of notice of the instant order, about any measures that the State has adopted in compliance with such order. ${ }^{120}$

5. To request the complainants to present their observations to the report presented by the state within 15 days after the report has been submitted.

${ }_{118}$ During pregnancy women sexual and reproductive health should be respected, and state authorities have a special duty to protect them.

119 African Charter, Article 1 "The Member States of the Organisation of African Unity, parties to the present Charter shall recognise the rights, duties and freedoms enshrined in the Charter and shall undertake to adopt legislative or other measures to give effect to them".

${ }^{120}$ Under 2010 Rules of Procedure, r 98(4) a state must respond within 15 days to a 'request' for PMs by indicating how it has implemented the 'request'. 
6. To receive in a private meeting during its next period of sessions the representatives of the beneficiaries, the beneficiaries of the provisional measures and the agents of the state.

\section{Conclusions}

Preventable maternal mortality violates several rights and affects multiple people. It constitutes a violation of the right to life, health, equality and non-discrimination of the women who do not obtain adequate medical care during pregnancy or delivering and it violates the rights of their relatives and communities who suffer from the loss. Preventable maternal mortality also constitutes a violation of the obligations assumed by states both at the international and the national level.

Unfortunately, preventable maternal mortality is a serious problem in Kenya. This country has kept for a long time high rates of maternal mortality. The decrease of the MMR has been very small- only 12 per cent - in 25 years. Although several (direct and indirect) structural factors, including women's low social status, malnutrition, lack of education and information, early marriage and unsafe abortions, could explain those deaths, this contribution focused on the factors related to inadequate health-care service. It was shown that expectant mothers are dying or become seriously ill in health facilities, frequently due to inadequate health services, weak trained health personnel, professional negligence and inadequate infrastructure. In other words, this contribution pointed out that some maternal deaths in Kenya are connected to the deplorable conditions in which pregnant women are attended in hospitals. Furthermore, the critical situation of health centres in Kenya and its negative impact on expectant mothers has been constantly reported by state organs, national and international NGOs, as well as by international human rights organs.

In this context this contribution suggests that the African Commission should use its competence to request PMs in order to protect expectant mothers. Provisional measures are a legal tool which should call the attention of international human rights bodies because their objective is to guarantee the practical effectiveness of rights, so that they are not just rhetorical and also because international human rights bodies and national tribunals are becoming more explicit, holding that maternal mortality is a human rights issue. In this sense, PMs could play an important role in guarantying expectant mothers their basic rights when they find themselves in an urgent situation. In the end what is most significant is the recognition that rights are not only included on an international plane and that states are internationally responsible in the event of their violation, but that all individuals, including women, can truly trust that those rights will be guaranteed in practice. ${ }^{121} \mathrm{PMs}$ are a legal tool which do not have the power to combat all the structural factors related to maternal mortality, however PMs have the potential to make safe maternity a reality in certain circumstances.

It must also be stressed that understanding maternal death in Kenya from a human rights perspective implies ensuring government accountability for policies and practices which lead to sexual and reproductive health rights violations, and it also implies empowering citizens in general and women in particular to advocate for their rights, and offering civil society a way to constructively engage in dialogue with national authorities about their responsibility to protect maternal health. Eight thousand maternal deaths occurred in Kenya in 2015, and these

\footnotetext{
${ }^{121}$ C Burbano Herrera, Provisional Measures in the Case Law of the Inter-American Court of Human Rights (2010 Intersentia) 1.
} 
deaths should not be called an unfortunate tragedy, but they are a scandalous social injustice and today it is time to think about this pressing societal issue seriously. 